\title{
Knowledge on human immunodeficiency virus mechanisms of transmission among schoolchildren in the age range of 11 to 20 years old from poor districts of Bucaramanga, Colombia
}

\author{
Jorge R. García-Corzo, M.D. ${ }^{a}$, Yolanda Tarazona-Álvarez, Psychologist ${ }^{b}$, \\ Johana P. Rojas-Gómez, Psychologist ${ }^{b}$, Eloísa del P. Bayona-Millán, Psychologist ${ }^{b}$ \\ and Luis A. Díaz-Martínez, M.D. ${ }^{a}$
}

a. School of

Medicine, School of Health, Universidad Industrial de Santander.

b. Secretariat of Social Welfare, Municipality of Bucaramanga. Bucaramanga, Colombia.

E-mail address: Jorge R. García Corzo, M.D.: jrgarciacor@gmail. com

\section{Funding:}

This study was funded by the Secretariat of Social Welfare of the Municipality of Bucaramanga and Universidad Industrial de Santander; both institutions facilitated the time devoted by their investigators to conduct this study and provided the necessary supplies.

\section{Conflict of interest:}

None.

Received: 04-26-2015 Accepted: 11-18-2015

\section{ABSTRACT}

Introduction. Human immunodeficiency virus (HIV) infection was the second most common cause of death, after injuries of external causes, among young adults from Bucaramanga in 2013. Objective. To establish the extent of knowledge on HIV mechanisms of transmission prevention strategies among schoolchildren in the age range of 13 to 20 years old from poor districts of Bucaramanga.

Methodology. Cross-sectional study among randomly selected schoolchildren using a selfadministered anonymous survey. For analysis, eachoutcomemeasureand binomialmodels for the association of answers by age, gender, education level and past sexual experience were described. Results. A survey was administered to 729 students ( $57 \%$ were girls); $50.6 \%$ of boys and $31.1 \%$ of girls reported having had sexual intercourse. Also, 58.6\% stated that a healthylooking person can have HIV. Besides, $69.1 \%$ indicated that HIV can be transmitted during pregnancy; $39.2 \%$, during delivery; $37.7 \%$, through breastfeeding; $79.7 \%$, through needle sharing; $29.5 \%$, by sharing food with someone who has HIV; and $31.7 \%$, by mosquito bites. In addition, $70.6 \%$ considered that they could prevent HIV by abstaining from having sexual relationships; $67.5 \%$, by having a single partner; and $80.0 \%$, by wearing condoms correctly. The proportion of adequate answers was not related to a higher education level, age, gender or sexual experience.

Conclusions. The quality of knowledge regarding HIV mechanisms of transmission and prevention is very poor, in spite of curricular contents providing sex education. It was observed that knowledge was not greater among those with higher education levels.

Key words: HIV, education, transmission, knowledge, adolescent.

http:/ /dx.doi.org/10.5546/aap.2016.eng.209

\section{INTRODUCTION}

In 2012, there were 2.1 million adolescents in low- and middleincome countries who had human immunodeficiency virus (HIV) infection worldwide, and 15-to-24 year-old individuals accounted for $42 \%$ of HIV incidence. ${ }^{1} \mathrm{~A}$ similar trend has been observed in America. In 2013, in the United States of America, 21\% of the HIV incidence was among individuals aged between 13 and 24 years old, and the highest number of diagnoses across all age groups was described in the 20-24 year-old range; the most commonly affected population were gay and bisexual men. ${ }^{2}$ In 2011, there were 1.4 million HIV-infected inhabitants in Latin America and the Caribbean; out of them, 250000 were 15 to 24 years old. ${ }^{1,3}$ In Colombia, half of the diagnoses made up to 2011 were in patients in their third or fourth decade. That same year, 6687 HIV cases were reported, with a prevalence of $0.3 \%$ among 15 -to24 year-old individuals $(0.4 \%$ were men and $0.1 \%$, women). Among reported cases, $2.6 \%$ corresponded to individuals younger than 18 years old, while $1.2 \%$ were younger than 15 years old ${ }^{4}$ but a significant underreporting has been observed.

In the city of Bucaramanga, HIV infection is the second leading cause of death among young adults, after injuries of external causes. ${ }^{5}$ Considering HIV latency period, many of these infections could have been acquired during adolescence. ${ }^{4,6}$

All this demonstrates that it is very important for adolescents to have basic knowledge on HIV risk factors and transmission prevention. ${ }^{7-10}$ In 
Colombia, a sex education program has been established to this end. ${ }^{11}$

The objective of this study was to establish the level of knowledge on HIV mechanisms of transmission and prevention strategies among students from the last four years of secondary education) attending schools located in the poor districts of Bucaramanga.

\section{MATERIALS AND METHODS}

A cross-sectional study was conducted in three districts of Bucaramanga (Colombia) at the end of the 2013 school year. In general, eighth graders are 14 years old; ninth graders, 15 years old; tenth graders, 16 years old; and eleventh graders, 17 years old. The study was approved by school authorities and the Ethics Committee of Universidad Industrial de Santander. Parents or legal tutors gave their written consent in advance, and students gave their written assent before completing the survey.

The sample size was estimated based on the information regarding the level of knowledge on HIV established by a previous local study, ${ }^{12}$ and a $95 \%$ accuracy was used. The sample size was adjusted considering a $15 \%$ loss rate, so 700 schoolchildren were invited to participate. The sample was stratified by type of participating school proportionally to the student population distribution as per school type (12\% of participants attended non-public schools).

The survey was anonymous and selfadministered, based on the UNAIDS 2011 AIS Individual_QRE_DHS6. ${ }^{13}$ This instrument is now standardized and has been used and validated in Honduras, and used in Colombia. ${ }^{3,4}$

Before conducting the study, a pilot test was done in a group of schoolchildren similar to that assessed in this study so as to verify its understandability. The survey was administered by the Secretariat of Social Welfare of the Municipality of Bucaramanga through 15 social workers, who distributed the instrument and collected it after completion during a 30-minute session in the classroom.

Answers to questions on HIV transmission or prevention were classified as correct or incorrect; the latter included questions that students answered as "do not know" and those for which students did not select any of the available options. The dependent outcome measure was defined as having comprehensive knowledge on HIV infection transmission and prevention, which was considered adequate if students answered 6-8 questions correctly out of the 8 questions on HIV transmission and 3-4 questions correctly out of the 4 questions on HIV prevention.

The prevalence of adequate answers and of comprehensive knowledge was established by gender and socioeconomic level; comparisons with an $\alpha<0.05$ as per the statistical test corresponding to each situation were considered significant. Finally, and to establish sociodemographic factors associated with the correct answer to each question and with having comprehensive knowledge, a prevalence odds ratio was obtained by means of an unconditional logistic regression and using Greenland's recommendations on

TABLE 1. Characteristics of participants by education level

\begin{tabular}{lllccc}
\hline Characteristic & $\mathbf{8}^{\text {th }}$ grade & $\mathbf{9}^{\text {th }}$ grade & $\mathbf{1 0}^{\text {th }}$ grade & $\mathbf{1 1}^{\text {th }}$ grade & Unspecified \\
\hline Participants & 198 & 190 & 172 & 144 & 25 \\
Boys & $88(44.4 \%)$ & $76(40.0 \%)$ & $76(44.2 \%)$ & $57(39.6 \%)$ & $15(60.0 \%)$ \\
Age (mean, SD) & $14.3(1.0)$ & $15.2(1.1)$ & $16.1(1.0)$ & $16.9(0.9)$ & $15.6(1.3)$ \\
Religious life & & & & \\
$\quad$ Active & $85(42.9 \%)$ & $78(41.1 \%)$ & $69(40.1 \%)$ & $65(45.1 \%)$ & $5(20.0 \%)$ \\
$\quad$ Mildly active & $29(14.7 \%)$ & $43(22.6 \%)$ & $28(22.1 \%)$ & $35(24.3 \%)$ & $8(32.0 \%)$ \\
$\quad$ Inactive & $13(6.6 \%)$ & $13(6.8 \%)$ & $11(6.4 \%)$ & $6(4.2 \%)$ & $4(16.0 \%)$ \\
$\quad$ No religious beliefs & $35(17.7 \%)$ & $28(14.7 \%)$ & $19(11.1 \%)$ & $14(9.7 \%)$ & $4(16.0 \%)$ \\
$\quad$ Not reported & $36(18.2 \%)$ & $28(14.7 \%)$ & $35(20.4 \%)$ & $24(16.7 \%)$ & $4(16.0 \%)$ \\
Sexual intercourse & $50(25.3 \%)$ & $63(33.2 \%)$ & $67(39.0 \%)$ & $67(46.5 \%)$ & $8(32.0 \%)$ \\
Use of hallucinogens & $40(20.2 \%)$ & $32(16.8 \%)$ & $30(17.4 \%)$ & $26(18.1 \%)$ & $6(24.0 \%)$ \\
\hline
\end{tabular}

SD: standard deviation. 
model development. ${ }^{14}$ Analysis was done using the Stata ${ }^{\circledR}$ SE 12.1 software (StataCorp LP, College Station, USA).

\section{RESULTS}

Seven hundred and sixty-one students were invited to participate; 729 (95.8\%) completed the survey; 411 (56.9\%) were girls, $308(42.8 \%)$ were boys, and $10(0.3 \%)$ did not indicate their gender. Age ranged from 11 to 20 years old (median: 16 years old), with no significant differences observed in terms of age between boys and girls (data not shown) or the proportion of boys and girls by grade. The demographic characteristics of participants by education level are shown in Table 1; 25 (3.4\%) schoolchildren did not indicate their grade.

A history of sexual intercourse by age range was reported by 39 out of 184 students younger than 15 years old $(21.2 \%)$, by 179 out of 474 students aged 15 to 17 years old $(37.8 \%)$, and by 34 out of 63 who were 18 or older $(54.0 \%)$, with a statistically significant difference $(p<0.001)$.

Among boys, 158 (50.6\%) reported having had sexual intercourse. Of these, $84.8 \%$ (134) had had heterosexual relationships, $4.4 \%$ (7), homosexual, and 10.8\% (17), bisexual. In turn, $129(31.1 \%)$ of women reported having had sexual intercourse; of them $89.9 \%$ (116) were heterosexual relationships, $5.4 \%$ (7), homosexual; and $4.7 \%$ (6), bisexual. Out of those who had had sexual intercourse, $103(40.4 \%)$ indicated that they had worn a condom the last time, with no significant differences between boys and girls.

Also, $9.6 \%$ of boys and $4.3 \%$ of girls who had had sexual intercourse had an HIV test, with a statistically significant difference $(p=0.005)$.

Among all schoolchildren, 276 (37.9\%) had smoked tobacco, 207 (28.4\%) had drunk alcohol in the past 30 days, and $134(18.4 \%)$ had used illegal psychoactive substances.

Table 2 shows the answers given by participants on HIV transmission and prevention by gender. There was no association between correct answers to each question and education level or personal characteristics of students, their past sexual experience or religious beliefs (data not shown).

The number of correct answers to each question is shown in Tables 3 and 4. No statistically significant differences were observed in terms of gender or education level. No differences were found when analyzing having comprehensive knowledge on HIV (transmission and prevention):
$20.2 \%$ of girls and $15.7 \%$ of boys $(p=0.117)$ demonstrated having comprehensive knowledge, while it was $16.7 \%$ among eighth graders, $18.4 \%$ among ninth graders, $19.8 \%$ among tenth graders, and $19.4 \%$ among eleventh graders $(p=0.845)$; these outcome measures had an odds ratio (OR) of 0.693, which was not significant (95\% confidence interval [CI]: 0.458-1.049) and 1.0 (95\% CI: 0.986-1.014), respectively. No associations were established by the model after doing a logistic regression.

No differences were observed between students who reported having used illegal psychoactive substances and those who had not $(17.7 \%$ versus $20.9 \%, p=0.379)$, those who reported having smoked and those who had not $(18.8 \%$ versus $17.0 \%, p=0.222)$ or between alcohol users and non-users (16.9\% versus $18.0 \%$, $p=0.791)$.

\section{DISCUSSION}

Bucaramanga schools have implemented the sex education program for students in accordance with the mandatory Sexuality and CitizenshipBuilding Education Program (Programa de Educación para la Sexualidad y Construcción de Ciudadania). ${ }^{11}$ This programs should provide students with the necessary knowledge on HIV. Schools where the study was conducted have been certified by the municipal supervisory body; however, only $58.6 \%$ of students indicated that a healthy-looking person could have HIV, which is concerning in the context of strategies for HIV prevention and non-discrimination against HIV-infected individuals. In this regard, there are remarkable variations. While in Australia $83 \%$ of students answered correctly, ${ }^{15}$ in Cuba, only $36.6 \%$ did, ${ }^{16}$ demonstrating that, in spite of curricular contents and their eagerness, there are major differences in terms of knowledge and, therefore, outcome.

A study conducted in Cartagena (Colombia) showed that $71.1 \%$ of students answered correctly that a healthy-looking person could be infected with HIV.${ }^{17}$ Why are there such differences among Colombian schools sharing the same curriculum? Probably in Cartagena, where tourism has varying effects, the focus is most likely put on the fact that an HIV-infected individual may be asymptomatic.

Likewise, knowledge is poor when it comes to HIV transmission related to pregnancy and breastfeeding. Only $37.7 \%$ of schoolchildren knew that HIV can be transmitted through breast milk (Cuban study: 50\%). ${ }^{16}$ 
TABLE 2. Knowledge on human immunodeficiency virus transmission and prevention by gender

\begin{tabular}{|c|c|c|c|c|}
\hline Question & Girls $(N=415)$ & Boys $(\mathrm{N}=312)$ & $P$ value & Total $(\mathrm{N}=729)$ \\
\hline \multicolumn{5}{|c|}{ Have you ever heard about HIV/AIDS? } \\
\hline Yes. & $403(97.1 \%)$ & $289(92.6 \%)$ & 0.083 & $694(95.2 \%)$ \\
\hline No. & $5(1.2 \%)$ & $12(3.9 \%)$ & & $17(2.3 \%)$ \\
\hline Does not know/does not answer. & $7(1.7 \%)$ & $11(3.5 \%)$ & & $18(2.5 \%)$ \\
\hline \multicolumn{5}{|c|}{ Can a healthy person be infected with HIV? } \\
\hline Yes (correct answer). & $252(60.7 \%)$ & $175(56.1 \%)$ & 0.140 & $427(58.6 \%)$ \\
\hline No. & $36(8.7 \%)$ & $29(9.3 \%)$ & & $65(8.9 \%)$ \\
\hline Does not know/does not answer. & $127(30.6 \%)$ & $108(34.6 \%)$ & & $137(32.5 \%)$ \\
\hline \multicolumn{5}{|c|}{ Can HIV be transmitted during pregnancy? } \\
\hline Yes (correct answer). & $313(75.4 \%)$ & $190(60.9 \%)$ & 0.003 & $504(69.1 \%)$ \\
\hline & $35(8.5 \%)$ & $29(9.3 \%)$ & & $74(6.5 \%)$ \\
\hline Does not know/does not answer. & $67(16.1 \%)$ & $93(29.8 \%)$ & & $198(27.2 \%)$ \\
\hline \multicolumn{5}{|c|}{ Can HIV be transmitted during delivery? } \\
\hline Yes (correct answer). & $165(39.8 \%)$ & $120(38.5 \%)$ & 0.992 & $286(39.2 \%)$ \\
\hline & $60(14.5 \%)$ & $47(15.1 \%)$ & & $107(14.7 \%)$ \\
\hline Does not know/does not answer. & $190(45.8 \%)$ & $145(46.5 \%)$ & & $336(46.1 \%)$ \\
\hline \multicolumn{5}{|c|}{ Can HIV be transmitted through breastfeeding? } \\
\hline Yes (correct answer). & $161(38.8 \%)$ & $113(36.2 \%)$ & 0.631 & $245(37.7 \%)$ \\
\hline No. & $52(12.5 \%)$ & $36(11.6 \%)$ & & $89(12.2 \%)$ \\
\hline Does not know/does not answer. & $202(48.7 \%)$ & $138(44.2 \%)$ & & $365(50.1 \%)$ \\
\hline \multicolumn{5}{|c|}{ Can HIV be transmitted by mosquito bites? } \\
\hline Yes. & $137(33.0 \%)$ & $94(30.2 \%)$ & 0.543 & $231(31.7 \%)$ \\
\hline No (correct answer). & $132(31.8 \%)$ & $109(34.9 \%)$ & & $243(33.3 \%)$ \\
\hline Does not know/does not answer. & $146(35.2 \%)$ & $109(34.9 \%)$ & & $255(35.0 \%)$ \\
\hline \multicolumn{5}{|c|}{ Can HIV be transmitted by sharing food with someone who has HIV? } \\
\hline Yes. & $118(28.4 \%)$ & $96(30.8 \%)$ & 0.870 & $215(29.5 \%)$ \\
\hline No (correct answer). & $156(37.6 \%)$ & $112(35.9 \%)$ & & $269(36.9 \%)$ \\
\hline Does not know/does not answer. & $141(34.0 \%)$ & $104(33.3 \%)$ & & $245(33.6 \%)$ \\
\hline \multicolumn{5}{|c|}{ Can HIV be transmitted by sharing needles? } \\
\hline Yes (correct answer). & $338(81.5 \%)$ & $241(77.2 \%)$ & 0.844 & $581(79.7 \%)$ \\
\hline No. & $19(4.5 \%)$ & $19(6.1 \%)$ & & $38(5.2 \%)$ \\
\hline Does not know/does not answer. & $59(14.0 \%)$ & $52(16.7 \%)$ & & $110(15.1 \%)$ \\
\hline \multicolumn{5}{|c|}{ What type of sexual relationship is a risk for HIV transmission? } \\
\hline Vaginal. & $292(70.4 \%)$ & $205(65.7 \%)$ & 0.626 & $498(68.3 \%)$ \\
\hline Oral. & $107(25.8 \%)$ & $97(30.1 \%)$ & 0.500 & $202(27.7 \%)$ \\
\hline Anal. & $124(29.8 \%)$ & $116(37.2 \%)$ & 0.131 & $240(32.9 \%)$ \\
\hline None. & $10(2.4 \%)$ & $7(2.2 \%)$ & 0.925 & $17(2.3 \%)$ \\
\hline Does not know. & $57(13.6 \%)$ & $34(10.8 \%)$ & 0.353 & $92(12.6 \%)$ \\
\hline \multicolumn{5}{|c|}{ Can special medications be used to reduce the risk of HIV transmission during pregnancy? } \\
\hline Yes (correct answer). & $121(29.2 \%)$ & $77(24.7 \%)$ & 0.566 & $198(27.2 \%)$ \\
\hline No. & $64(15.4 \%)$ & $51(16.4 \%)$ & & $116(19.5 \%)$ \\
\hline Does not know/does not answer. & $230(55.4 \%)$ & $184(59.0 \%)$ & & $415(56.9 \%)$ \\
\hline \multicolumn{5}{|c|}{ Can HIV be prevented by abstaining from having sexual intercourse? } \\
\hline Yes (correct answer) & $295(71.1 \%)$ & $219(70.2 \%)$ & 0.463 & $515(70.6 \%)$ \\
\hline No. & $65(15.7 \%)$ & $47(15.1 \%)$ & & $112(15.4 \%)$ \\
\hline Does not know/does not answer. & $55(13.2 \%)$ & $46(14.7 \%)$ & & $102(14.0 \%)$ \\
\hline \multicolumn{5}{|c|}{ Can HIV be prevented by having sexual intercourse with only one faithful uninfected partner? } \\
\hline Yes (correct answer). & $294(70.9 \%)$ & $197(63.1 \%)$ & 0.160 & $492(67.5 \%)$ \\
\hline No. $\quad$ & $44(10.5 \%)$ & $52(16.7 \%)$ & & $97(13.3 \%)$ \\
\hline Does not know/does not answer. & $77(18.6 \%)$ & $63(20.2 \%)$ & & $140(19.2 \%)$ \\
\hline \multicolumn{5}{|c|}{ Can HIV be prevented by correctly wearing a condom? } \\
\hline Yes (correct answer). & $325(78.3 \%)$ & $256(82.1 \%)$ & 0.532 & $583(80.0 \%)$ \\
\hline No. & $28(6.8 \%)$ & $19(6.1 \%)$ & & $47(6.5 \%)$ \\
\hline Does not know/does not answer. & $62(14.9 \%)$ & $37(11.8 \%)$ & & $99(13.6 \%)$ \\
\hline
\end{tabular}


Also in our study, only $33.3 \%$ knew that HIV cannot be transmitted by mosquito bites. This is a common misconception. In Australia, only $36 \%$ of students were aware that HIV is not transmitted like this. ${ }^{15}$ A similar rate was observed in Cuba $(21.6 \%),{ }^{16}$ China $(40 \%-60 \%)^{18,19}$ and other cities of Colombia. ${ }^{17}$ Such misunderstandings may weaken any effort to educate and convince adolescents to implement adequate prevention measures (abstinence, monogamy, wearing a condom) by taking the attention from actual risk factors and placing it on wrong ideas that cannot by controlled by individuals.

Risk factors for HIV among adolescents include being a man who has sex with men ( $72 \%$ of incidence in the United States of America), having multiple sexual partners, being an injection drug user, and having unprotected sex. ${ }^{2}$ In Colombia, the main reasons given not to wear a condom include believing that it reduces pleasure, being aroused by or under the effect of psychoactive substances, and not wanting to wear it in spite of being aware of the risks. ${ }^{4}$

Almost two-thirds of schoolchildren indicated that HIV can be transmitted by sharing food with an infected person, which leads to discrimination against HIV-infected individuals, something not unusual in Latin America. ${ }^{16}$ Only 34.4\% knew HIV is transmitted by sharing needles, a percentage much lower than that observed in Cuba or Australia. ${ }^{15,16}$ This is a major concern, especially because IV drug use is part of the dramatic and concerning context of addiction that is taking place in the cities.

Only $32.9 \%$ of students included in our study knew that anal sex is a risk for HIV transmission. Together with the popular assumption that anal intercourse may be a form of contraception and the influence of pornography, individuals become

TABLE 3. Number of correct answers to questions related to human immunodeficiency virus transmission by gender and education level

\begin{tabular}{lcccc}
\hline Characteristic & \multicolumn{3}{c}{ Correct answers } & P value \\
& $\mathbf{0 - 2}$ & $\mathbf{3 - 5}$ & $\mathbf{6 - 8}$ & \\
\hline $\begin{array}{l}\text { Gender } \\
\text { Girls }\end{array}$ & $56(13.5 \%)$ & $236(56.9 \%)$ & $123(29.6 \%)$ & 0.063 \\
Boys & $62(19.9 \%)$ & $160(51.3 \%)$ & $90(28.9 \%)$ & \\
Grade & & & & \\
$8^{\text {th }}$ & $40(20.2 \%)$ & $107(54.4 \%)$ & $51(27.8 \%)$ & 0.429 \\
$9^{\text {th }}$ & $32(16.8 \%)$ & $104(54.7 \%)$ & $54(28.4 \%)$ & \\
$1^{\text {th }}$ & $23(13.4 \%)$ & $90(52.3 \%)$ & $59(34.3 \%)$ & \\
$1^{\text {th }}$ & $18(12.5 \%)$ & $83(57.6 \%)$ & $43(29.9 \%)$ & \\
\hline
\end{tabular}

exposed to a greater risk. This is similar to what has been observed in Cuba, where only 22\%-33\% of students considered that anal intercourse was a risk. ${ }^{17,20}$

Also, $70.6 \%$ of respondents considered that abstaining from having sexual relationships protected them against HIV; $67.5 \%$, if they had sex with only one partner, and $80.0 \%$ indicated that correctly wearing a condom reduced the risk of HIV infection. These percentages are lower than those seen in Australia (88\%) and Cuba (89\%-95\%), but higher than what has been observed in Cartagena (63.1\%). ${ }^{15,17,20}$

The situation becomes more revealing when analyzing comprehensive knowledge on HIV: there were no differences by gender and, contrary to what was expected, either among older students or those with a higher education level. In Mexico, characteristic answer patterns within each socioeconomic level were observed to be different from those of other socioeconomic levels, and higher rates of correct answers corresponded to those with more financial resources, i.e. those who had access to a better educational quality. ${ }^{21}$ In Venezuela, significant differences were observed in favor of women. ${ }^{22}$

A study conducted in Minas Gerais (Brazil) used a general knowledge indicator with nine questions; the median number of correct answers was five: 1 (0-3) and 4 (0-6) for questions about risks and transmission, respectively. Only 1.3\% of adolescents answered each question correctly, which demonstrates that such poor results are common across South America. ${ }^{23}$

Such knowledge gap may be related to a behavioral pattern of sexual risk, as that observed in $36 \%$ of adolescents from Santa Marta (Colombia) who had a history of sexual intercourse. ${ }^{24}$ In this case, such pattern was

TABLE 4. Number of correct answers to questions related to human immunodeficiency virus transmission by gender and education level

\begin{tabular}{lccc}
\hline Characteristic & $\begin{array}{c}\text { Correct } \\
\mathbf{0 - 2}\end{array}$ & $\begin{array}{c}\text { Answers } \\
\mathbf{3} \text { or 4 }\end{array}$ & P value \\
\hline $\begin{array}{c}\text { Gender } \\
\text { Girls }\end{array}$ & $195(47.0 \%)$ & $220(53.0 \%)$ & 0.584 \\
Boys & $153(49.0 \%)$ & $159(51.0 \%)$ & \\
Grade & & & \\
$8^{\text {th }}$ & $91(46.0 \%)$ & $107(54.0 \%)$ & 0.730 \\
$9^{\text {th }}$ & $91(48.0 \%)$ & $99(52.1 \%)$ & \\
$1^{\text {th }}$ & $85(49.4 \%)$ & $87(50.6 \%)$ & \\
$1^{\text {th }}$ & $67(46.5 \%)$ & $77(53.5 \%)$ & \\
\hline
\end{tabular}


defined as two or more risky sexual behaviors, which was more common among individuals who had used illegal substances and alcohol.

In our study, an inadequate knowledge on HIV was not related to the use of illegal substances and alcohol; however, this may have been distorted by the generalized poor level of knowledge, which may conceal other differences that would otherwise be revealed.

Such findings of insufficient knowledge among poor adolescents from Bucaramanga imply a great vulnerability, especially considering that adolescents with adequate knowledge on HIV do not necessarily implement prevention strategies. ${ }^{10,25}$ Thus, having information is not enough to generate a responsible sexual behavior, given that external factors have an effect on each individual, allowing such behavior to take place or not, ${ }^{23,25-28}$ and these include believing that HIV is easily treated or that there will soon be a cure.

Studies on the effectiveness of sex education and HIV programs have demonstrated that a major indicator of sexual activity is age at sexual initiation. Programs that accomplish the greatest impact on HIV risky behaviors are those that achieve a significant delay in sexual initiation. $4,7,8,10,15,21,22,24,29-33$

Other important objectives of these programs include wearing condoms and reducing the number of sexual partners; however, unexpected effects occur sometimes, given that $3 \%$ of participants increased their number of sexual partners. ${ }^{9}$ Sex education programs may fail to accomplish knowledge goals, so a comprehensive vision of sociocultural context is required to generate adequate curricular contents, in addition to taking into consideration successful programs. Implementing programs from other parts of the world is not enough. Programs that have evidenced the greatest level of effectiveness and applicable to our population should be targeted, given that the tendency in the long run is that adolescents will not be capable of adequately recognizing risk factors for sexually transmitted infections. ${ }^{34}$

This study has several limitations: surveys may have been biased; it has been observed that, in relation to questions regarding risky behaviors, if asked to the same adolescents at a different moment, answers had changed. This study included students from the last four years of secondary education, and its reliability may be reduced in relation to students from the lower grades. For this study, self-administered surveys were used because they appear to be more dependable that those administered by a survey-taker.

Each item was given the same value. In practical terms, some concepts are more relevant than others in terms of HIV prevention, so knowing these implies a greater protective effect; however, we were not able to assign them such value or score in our context, and could not find information on this matter in the literature. It might be interesting to look into this subject in future studies. Also, this study did not include schoolchildren from other socioeconomic levels, so it is not possible to make comparisons.

\section{CONCLUSIONS}

The quality of knowledge on HIV transmission and prevention among secondary education students from poor districts of Bucaramanga is quite inadequate and was not observed to improve among higher education levels.

\section{REFERENCES}

1. United Nations. Global report: UNAIDS report on the global AIDS epidemic 2013. Geneva: UNAIDS; 2013. [Accessed on: October 5, 2014]. Available at: http://www.unaids. org/sites/default/files/media_asset/UNAIDS_Global_ Report_2013_en_1.pdf.

2. Centers for Disease Control and Prevention. HIV Surveillance Report 2013, Volume 25. Atlanta: CDC; 2015. [Accessed on: July 2, 2015]. Available at: http://www. cdc.gov/hiv/pdf/library/reports/surveillance/cdc-hivsurveillance-report-vol-25.pdf.

3. Honduras. Instituto Nacional de Estadística. Encuesta Nacional de Demografía y Salud ENDESA 2011-2012. Tegucigalpa: INE; 2013. [Accessed on: August 15, 2014]. Available at: http://www.ine.gob.hn/index.php/ component $/$ content $/$ article?id=67.

4. Colombia. Ministerio deSalud y Protección Social. Informe mundial de avances en la lucha contra el SIDA (UNGASS) 2012. [Accessed on: July 9, 2013]. Available at: https:// www.minsalud.gov.co/salud/Documents/UNGASS $\% 20$ 2012\%20FINAL_distribuido.pdf.

5. Colombia. Ministerio de Salud y Protección Social. Secretaría de Salud de Santander. Grupo de Vigilancia en Salud Pública. Análisis de situación de salud con el modelo de los determinantes sociales de salud. Municipio de Bucaramanga 2014. [Accessed on: November 26, 2015]. Available at: http://observatorio.co/web2/index.php/ publicaciones/publicaciones-especiales/asis-municipalsantander-2014/554-bucaramanga/file

6. Villarruel AM, Jemmott JB 3rd, Jemmott LS. A randomized controlled trial testing an HIV prevention intervention for Latino youth. Arch Pediatr Adolesc Med 2006;160(8):772-7.

7. Jemmott JB 3rd, Jemmott LS, Fong GT. Efficacy of a theorybased abstinence-only intervention over 24 months: a randomized controlled trial with young adolescents. Arch Pediatr Adolesc Med 2010;164(2):152-9.

8. Jemmott JB3rd, Jemmott LS, Ngwane Z, Zhang J, et al. Theory-based behavioral intervention increases selfreported physical activity in South African men: a clusterrandomized controlled trial. Prev Med 2014;64:114-20.

9. Kirby DB, Laris BA, Rolleri LA. Sex and HIV education 
programs: their impacton sexual behaviors of young people throughout the world. J Adolesc Health 2007;40(3):206-17.

10. Shrier LA. Sexually transmitted diseases in adolescents: biologic, cognitive, psychologic, behavioral, and social issues. Adolesc Med Clin 2004;15(2):215-34.

11. Colombia. Ministerio de Educación Nacional. Evaluación del Programa de Educación para la Sexualidad y Construcción de Ciudadanía. Informe final, 2008.

12. Castillo M, Meneses M, Silva JL, Navarrete PA, et al. Prevalencia de relaciones sexuales en adolescentes estudiantes de un colegio de Bucaramanga, Colombia. MedUNAB 2003;6(18):137-43.

13. The Demographic and Health Surveys (DHS) Program. AIS Model Questionnaires. [Accessed on: March 10, 2013]. Available at: http://dhsprogram.com/What-We-Do/ Survey-Types/AIS-Questionnaires.cfm.

14. GreenlandS. Multiple comparisons and association selection in general epidemiology. Int J Epidemiol 2008;37(3):430-4.

15. Smith A, Agius P, Mitchell A, Barrett C, et al. Secondary students and sexual health 2008. Melbourne: Australian Research Centre in Sex, Health \& Society, La Trobe University; 2009. [Accessed on: July 18, 2013]. Available at: https://www.latrobe.edu.au/arcshs/downloads/arcshsresearch-publications/secondary-students-and-sexualhealth-2008.pdf.

16. González Valcárcel B, Nuñéz Aragón E, Couturejuzon González L, Amable Ambrós Z. Conocimientos y comportamientos sobre el VIH/SIDA en adolescentes de enseñanza media superior. Rev Cubana Salud Publica 2008;34(2):1-8.

17. Gómez-Bustamante E, Cogollo-Milanés Z. Conocimiento sobre VIH-SIDAen estudiantes de secundaria deCartagena, Colombia. Rev Salud Pública 2011;13(5):778-84.

18. Albrektsson M, Alm L, Tan X, Andersson R. HIV/AIDS awareness, attitudes and risk behavior among university students in Wuhan, China. Open AIDS J 2009;3:55-62.

19. Sun X, Liu X, Shi Y, Wang Y, et al. Determinants of risky sexual behavior and condom use among college students in China. AIDS Care 2013;25(6):775-83.

20. Fadragas A, Valdés M, Fernández LM. Caracterización del nivel de información sobre ITS/SIDA en adolescentes de la escuela secundaria José Luis Arruñada . Rev Cuba Med Gen Integr 2012;28(1):15-25.

21. Caballero-Hoyos R, Villaseñor-Sierra A. Conocimientos sobre VIH/SIDA en adolescentes urbanos: consenso cultural de dudas e incertidumbres. Salud Pública Méx 2003;45(Suppl 1):s108-14.
22. Dávila ME, Tagliaferro AZ, Bullones X, Daza D. Nivel de conocimiento de adolescentes sobre VIH/SIDA. Rev Salud Pública 2008;10(5):716-22.

23. Moura LR, Lamounier JR, Guimarães PR, Duarte JM, et al. The gap between knowledge on HIV / AIDS and sexual behavior: a study of teenagers in Vespasiano, Minas Gerais State, Brazil. Cad Saude Publica 2013;29(5):1008-18.

24. Campo-Arias A, Ceballo GA, Herazo E. Prevalencia de patrón de comportamiento de riesgo para la salud sexual y reproductiva en estudiantes adolescentes. Rev LatinoAm Enfermagem 2010;18(2):170-4

25. Camargo BV, Barbará A. Efeitos de panfletos informativos sobre a AIDS em adolescentes. Psic Teor Pesq 2004;20(3): 279-87.

26. Kann L, Kinchen S, Shanklin SL, Flint KH, et al. Youth risk behavior surveillance - United States, 2013. MMWR Surveill Summ 2014;63(Suppl 4):1-168.

27. Kaiser Family Foundation. National survey of teens and young adults on HIV/AIDS. Menlo Park: KFF; 2012 [Accessed on: November 1, 2014]. Available at: https://kaiserfamilyfoundation.files.wordpress. com/2013/01/8386-c.pdf.

28. Trajman A, Belo MT, Teixeira EG, Dantas VC, et al. Conhecimento sobre DST / AIDS e comportamento sexual entre estudantes do ensino médio no Rio de Janeiro, Brasil. Cad Saude Publica 2003;19(1):127-33.

29. Camargo BV, Bertoldo RB. Comparação da vulnerabilidade de estudantes da escola pública e particular em relação ao HIV. Est Psicol 2006;23(4):369-79.

30. Jemmott JB 3rd, Jemmott LS, O'Leary A, Ngwane Z, et al. School-based randomized controlled trial of an HIV /STD risk-reduction intervention for South African adolescents. Arch Pediatr Adolesc Med 2010;164(10):923-9.

31. Jemmott LS, Jemmott JB 3rd, Ngwane Z, Icard L, et al. 'Let Us Protect Our Future' a culturally congruent evidencedbased HIV/STD risk-reduction intervention for young South African adolescents. Health Educ Res 2014;29(1):166-81.

32. Espada JP, Morales A, Orgiles M, Jemmott JB 3rd, et al. Short-term evaluation of a skill-development sex education program for Spanish adolescents compared with a wellestablished program. J Adolesc Health 2015;56(1):30-7.

33. O'Leary A, Jemmott JB 3rd, Jemmott LS, Teitelman A, et al. Associations between psychosocial factors and incidence of sexually transmitted disease among South African adolescents. Sex Transm Dis 2015;42(3):135-9.

34. Beltzer N, Saboni L, Sauvage C, Lydié N, et al. An 18-year follow-up of HIV knowledge, risk perception, and practices in young adults. AIDS 2013;27(6):1011-9. 